\title{
Changes in Community Composition Following Secondary Succession of a Temperate Oak- hornbeam Forest After Grassland Abandonment and Their Effect on Soil Carbon and Nutrient Pools
}

\section{Antun Jelinčić ( $\square$ antunjelincic@gmail.com )}

Independent researcher https://orcid.org/0000-0002-6274-4764

Dora Papković

Independent researcher

Željka Zgorelec

University of Zagreb Faculty of Agriculture: Sveuciliste u Zagrebu Agronomski Fakultet

Aleksandra Perčin

University of Zagreb Faculty of Agriculture: Sveuciliste u Zagrebu Agronomski Fakultet

\section{Research}

Keywords: ecosystem development, forest development, soil-vegetation relationships, chronosequence, karst soil, nutrient retention, temporal community changes

Posted Date: November 29th, 2021

DOI: https://doi.org/10.21203/rs.3.rs-1083160/v2

License: (c) (i) This work is licensed under a Creative Commons Attribution 4.0 International License.

Read Full License 


\section{Abstract}

To date, changes in $\mathrm{C}$ and nutrient cycling during succession are somewhat studied, however, results are often contrasting for different nutrients and successional sequences. Generally, due to increment of litter rich in lignocellulosic components during late succession, mineralization of nutrients is expected to decelerate, and large amounts of nutrients become captivated within tree biomass. We investigated the changes in community composition following secondary succession of oak-hornbeam forest after grassland abandonment, along with the differences in soil chemistry between early- and latesuccessional stages. We aimed to discover whether late succession increases soil organic $\mathrm{C}$ and total $\mathrm{N}$ and $\mathrm{S}$ pool, but decreases the pools of plant available $\mathrm{P}$ and $\mathrm{K}$, and that of micronutrients due to their captivation within the tree biomass.

The successional sequence studied had a following pathway: Helictotrichon pubescens haypastures à Brachypodium pinnatum successional grasslands à Cornus sanguinea scrubs à late-successional Populus tremula forests à late-successional oak-hornbeam (Quercus-Carpinus) forests. Total species number was highest in haypastures and lowest in late-successional $P$. tremula forest. Species richness of haypastures was higher from that of mid-successional scrub and late-successional forest stages. Species richness did not differ between mid-successional scrub and late-successional forest stages. Occurrences of plant species throughout secondary succession was mostly stage-specific; only Fragaria vesca, Ajuga reptans, Cornus sanguinea, Prunus spinosa, and Viola hirta showed survival ability throughout almost all stages. Late-successional forest stages had a higher soil organic carbon (SOC), soil organic matter (SOM), and $\mathrm{K}_{\mathrm{A}}$ concentration, along with the higher soil $\mathrm{C}: \mathrm{N}$ and $\mathrm{C}: \mathrm{S}$ ratio in $\mathrm{A}$ horizon compared to early-successional grassland stages, whereas concentrations of plant available $P$ and total $\mathrm{N}, \mathrm{S}, \mathrm{Mn}, \mathrm{Zn}, \mathrm{Ni}, \mathrm{Cu}$, and Fe remained unaltered.

Even though late-successional forest stages tighten the nutrient cycles through nutrient captivation within the tree biomass, we found that late succession efficiently retained $\mathrm{P}_{\mathrm{A}}$ and micronutrient pools and even increased $\mathrm{K}_{\mathrm{A}}$ concentration in the $\mathrm{A}$ horizon, despite the fact that great amounts of these nutrients were already excluded from the nutrient cycle. Despite the contradicting $\mathrm{C}$ inputs, soil total $\mathrm{N}$ and $\mathrm{S}$ concentration did not differ between late-successional forest and early-successional grassland stages.

\section{Introduction}

In the last few decades, changes in soil chemistry and nutrient cycling following both primary and secondary succession have been well studied; however, the available data is still insufficient to identify general patterns of how different successional stages alter soil chemical properties, especially soil nutrient pools. Effort has been made to postulate general rules that describe parallel changes in gross and net primary production during ecosystem development with soil nutrient cycling (Odum, 1969; Vitousek, 1975; Robertson and Vitousek, 1981), but the main limitation of these rules is that they can differ across biomes, vegetation sequences, soil types, and land use histories of the terrain on which succession is studied. Odum (1969) formulated 24 hypothesis of ecosystem development, three of which 
were directly linked to nutrient cycling, and since then, these three hypotheses were tested several times, yielding somewhat mixed results.

To date, most of the effort in describing the links between vegetation succession and nutrient cycling has been made regarding $\mathrm{N}$ cycling, and somewhat less regarding P cycling (Robertson and Vitousek, 1981; Zak et al., 1990; Huang et al., 2013; Zhang et al., 2015), because these two macronutrients are typically the most limiting in ecosystem development. On the other hand, not many studies have investigated the cycling of K, Ca, and Mg (Bautista-Cruz and del Castillo, 2005; Feldpausch et al., 2004), and to our knowledge, no studies have focused on the cycling of micronutrients during vegetation succession.

Due to the different functional composition between most grassland and forest communities, it can be expected that these two vegetation types exert a different influence on nutrient retention and cycling. Plants in most early successional stages (except those growing on very nutrient-poor soils) are often characterized by lower $\mathrm{C}: \mathrm{N}$ and $\mathrm{C}: \mathrm{P}$ ratios, higher $\mathrm{N}$ and $\mathrm{P}$ contents, and lower content of lignocellulosic components in their tissues than those of species from late-successional stages, such as forests (Cortez et al., 2007; Poorter et al., 2004; Vitousek et al., 1988). Therefore, it can be expected that litter mineralization would be much faster in early-successional grasslands than in late-successional stages, as the high $\mathrm{C}$ content (especially lignin content) in the tissues of late-successional tree species delays the release of nutrient forms available to plants. For example, the release of nutrients from woody litter sometimes begins after as much as 60 years (Lambert et al., 1980). In addition, large amounts of nutrients are locked within the tree biomass and excluded from the nutrient cycle, which is why except in very fertile soils, the further supply of soil nutrients in forests often mainly depends on the amounts of nutrients available from parent material weathering, litter mineralization, or atmospheric deposition in the case of $\mathrm{N}$ and $\mathrm{S}$ in polluted areas (Vitousek et al., 1988). Furthermore, when mineralized, nutrients in forest soils are expected to be retained in the soil for only a short time because of their fast acquisition (i.e. recycling) by trees; for this reason, Odum (1969) suggested that nutrient cycles in late succession (i.e. forest stages) should be called "closed cycles". Despite the general differences in the abovementioned functional traits between early and late-successional species, the results of previous studies on the influence of succession on soil nutrient pools are still somewhat unclear.

Changes in plant community composition following both primary and secondary succession have been somewhat studied on a global scale. However, these changes are biome-specific, and they can even differ within a single study area of the same climate and same climax community. This can make it hard to formulate some generalizations about floristic changes during succession, except in the cases when generalizations are made for a specific area of interest. In Croatia, vegetation succession is poorly studied. Only rare data is available on grassland succession (Kutnjak, 2010; Krstonošić et al., 2016), whereas somewhat more comprehensive research on the whole successional sequences has been carried out in the neighboring country of Slovenia (Čarni et al., 2007; Čarni et al., 2020; Dakskobler, 2010).

The aims of the present study were: (i) to examine the changes in community composition following secondary succession of temperate oak-hornbeam forests after grassland abandonment in NW Croatia; 
(ii) to assess whether late succession (i.e. forest stages) decreases the concentrations of $P_{A}, K_{A}$, and micronutrients in the A horizon as a consequence of their captivation within the tree biomass, but increases soil total $\mathrm{N}$ and $\mathrm{S}$ concentrations, as well as organic $\mathrm{C}$ and organic matter content in contrast to those in early succession (i.e. grassland stages). Species nomenclature in this study followed The Plant List version 1.01 (2013).

\section{Materials And Methods}

\subsection{Study site}

The study was conducted in NW Croatia, in the surroundings of the village Brlog Ozaljski $\left(45^{\circ} 37^{\prime} 32.37^{\prime \prime}\right.$ $\left.\mathrm{N}, 15^{\circ} 24^{\prime} 11.09^{\prime \prime} \mathrm{E}\right)$. The mean annual rainfall of the study site ranges between 1000 and $1200 \mathrm{~mm}$, mean annual temperature is $9-10^{\circ} \mathrm{C}$, and the mean temperatures of the coldest (January) and warmest month (July) range from -2 to $-1^{\circ} \mathrm{C}$ and from 19 to $20^{\circ} \mathrm{C}$, respectively (Zaninović et al., 2008). The soil type the study was conducted on was slightly leached (i.e. lesivated) calcocambisol (Husnjak, 2014; Bogunović, 1998) on biolithitic and bioclastic limestones (Bukovac, 1984). In WRB classification (2006), this soil type corresponds to calcic cambisol. This is the dominant soil type in the study area, with district cambisol on quaternary quartz sands, gravels, and red siltose and grey clays as inclusions (Bukovac, 1984; Bogunović, 1998). In the study area, during the last few decades, the abandonment of agricultural land use led to a progression of vegetation succession, resulting in significant loss of meadow and pasture communities. Today, the remaining meadows are dominated by grass species Helictotrichon pubescens and are used as haypastures, i.e. for obtaining hay, but are also occasionally used for lowintensity rotational grazing by sheep.

\subsection{Vegetation survey and soil sampling}

The sequence of vegetation succession was studied using the space for time substitution, and five stages of succession were included in the study (Fig. 1). The investigated successional stages were selected to be near one another as much as possible and in a relief conditions as similar as possible in order to exclude the influence of differing slope and exposition. The vegetation survey was performed throughout May, June, July, and August 2020, using five $100 \mathrm{~m}^{2}$ plots $(10 \times 10 \mathrm{~m})$ within each successional stage, totaling 25 plots. Species cover in grasslands was recorded using the phytosociological scale of Barkman et al. (1964), and in scrub and forest stages using the scale of BraunBlanquet (1964).

For the analyses of differences in soil pH, SOC, and nutrient concentrations between the two end-points of succession, six pairs of early-successional grassland and late-successional forest stages located next to each other were selected. Every pair of grassland and forest plots represented a block (i.e. randomized block design). The grasslands selected for this purpose were recently used haypastures undergoing colonization with successional grasses, whereas forest plots selected for this purpose were latesuccessional mixed stands of $P$. tremula, $C$. betulus, and $Q$. petraea and/or $Q$. robur (see the footnotes in 
Table A1). Both grassland and forest plots selected for the soil analyses belonged to the same chronosequence used to study the changes in community composition. Soil was sampled at the depth of 0-10 cm, which corresponded to the A horizon. Soil sampling was performed from February 28 to March 22020 , before the beginning of the vegetation season. This time of the year was chosen for soil sampling because most of the nutrients were still retained in the soil and were not yet acquired by vegetation; thus, we wanted to examine their statuses in the surface soil before uptake by vegetation. Litter leftovers were removed from the soil samples. The soil was not sampled from the scrub stage of $C$. sanguinea as it is a mid-successional stage.

\subsection{Soil laboratory analyses}

Soil analyses were carried out using air-dried, homogenized, and sieved soil samples ( $<2 \mathrm{~mm}$ sieve) (prepared according to the protocol ISO 11464). We determined the soil pH in 1:2.5 (w/v) soil suspension in $1 \mathrm{M} \mathrm{KCl}$ (modified ISO 10390). Organic $\mathrm{C}$, and total $\mathrm{N}$ and $\mathrm{S}$ concentrations were determined by the dry combustion method (HRN ISO 10694:2004, HRN ISO 13878:2004, and HRN ISO 15178:2005, respectively). Soil organic matter content was calculated according to Škorić (1982). Plant available P and $\mathrm{K}$ were extracted with an ammonium lactate (AL) solution (Egner et al., 1960) and their concentrations were detected by spectrophotometry and flame photometry, respectively. Total concentrations of $\mathrm{Mn}, \mathrm{Zn}, \mathrm{Fe}, \mathrm{Cu}$, and $\mathrm{Ni}$ were determined using the pXRF method with an Olympus-Vanta C series portable X-ray fluorescence analyzer (HRN EN ISO 13196:2015).

\subsection{Statistical analyses}

Differences in community composition between the successional stages were plotted with non-metric multidimensional scaling (NMDS) using a dissimilarity matrix constructed with Bray-Curtis dissimilarities. Prior to the NMDS, cover values of species occurring in more than one vegetation layer were pooled, and all of the cover values were transformed to type I ordinal percentage scale (Van der Maarel, 2007). Differences in mean species richness between the successional stages were analyzed by one-way ANOVA, followed by Tukey's post-hoc pairwise comparison test.

The differences in soil chemistry between early and late succession were analyzed by two-way ANOVA without replication in order to account for inter-site variation (i.e. the block effect). One-way ANOVA without blocking was used for the variables that were not significantly influenced by inter-site variation (i.e. if the block effect was $>0.25$ ). Threshold value of 0.25 was chosen for assessing the significance of the block effect because it is stricter than the traditional threshold of 0.05 for the purpose of determining the inter-site variation of the soil chemical properties. All data were analyzed using the PAST 4.03 software (Hammer et al., 2001).

\section{Results}

\subsection{Differences in community composition following secondary succession}


The NMDS ordination plot (Fig. 2) provided a very good representation of the community composition differences between the successional stages of the analyzed chronosequence, with a final stress for 2D solution of $11 \%$. Early-successional stages (i.e. haypastures and B. pinnatum-dominated successional grasslands) were grouped close together and ordinated on the negative side of the first axis, whereas latesuccessional stages (i.e. P. tremula forests and oak-hornbeam forests) were ordinated on the positive side of the first axis, and $C$. sanguinea scrubs were ordinated in the middle between all other stages.

Figure 3 shows the differences in species richness (i.e. number of species per plot) between the different successional stages. Species richness of haypastures was significantly higher than that of midsuccessional $C$. sanguinea scrubs, as well as that of late-successional $P$. tremula forests and oakhornbeam forests. There were no significant differences in mean species richness between mid-and latesuccessional stages. Species richness of successional grasslands dominated by $B$. pinnatum significantly differed from that of $P$. tremula forests, but did not differ from that of $C$. sanguinea scrubs and oak-hornbeam forests. Species richness of different succession stages was as follows: haypastures had an average of 41 species per $100 \mathrm{~m}^{2}$; successional grasslands had an average of 32 species per 100 $\mathrm{m}^{2}$; $C$. sanguinea scrubs had an average of 26 species per $100 \mathrm{~m}^{2}$; late-successional $P$. tremula forests had an average of 20 species per $100 \mathrm{~m}^{2}$; and late-successional oak-hornbeam forests had an average of 24 species per $100 \mathrm{~m}^{2}$. Full results of Tukey pairwise comparison test are given in Table A3.

Total species number in haypastures, successional grasslands, $C$. sanguinea scrubs, $P$. tremula forests, and oak-hornbeam forests was $76,72,59,46$, and 59 , respectively.

\subsection{Floristic characteristics of individual succession stages}

Plant community composition of individual successional stages within the analyzed chronosequence is listed in Table A1.

1. Haypastures (HP)

With the highest overall abundance, the dominant species of haypastures was the grass Helictotrichon pubescens. Among other grass species, Anthoxanthum odoratum and Trisetum flavescens appeared in all five plots with somewhat high overall abundance, followed by Holcus lanatus appearing in four plots, also with high overall abundance, and Dactylis glomerata and Festuca ovina appearing in four plots with low abundance. Trifolium pratense was the most abundant legume, appearing in all five plots, followed by less abundant T. repens, appearing in four plots. Among Asteraceae, Leucanthemum vulgare, Achillea millefolium, and the invasive Erigeron annuus appeared in all five plots, followed by Leontodon hispidus appearing in four plots. Among Lamiaceae, only Clinopodium vulgare appeared in all five plots, and among Apiaceae, Pimpinella saxifraga was the most abundant species, also appearing in all five plots. Other frequent species in haypastures appearing in all five plots were Plantago lanceolata, Fragaria 
vesca, and Ranunculus bulbosus, and those appearing in four plots were Polygala comosa, Daucus carota, Galium mollugo, G. verum, Ranunculus acris, Rumex acetosa, and Veronica chamaedrys.

\section{Successional grasslands (SG)}

In successional grasslands, the grass Brachypodium pinnatum was the dominant species. Calamagrostis epigejos appeared only in two plots, but was found in the study area forming patches within $B$. pinnatum grasslands. Other species occurring in all five plots were the grasses Dactylis glomerata and Briza media, along with the mid-successional species Cornus sanguinea and Prunus spinosa occurring in the herb layer. Species occurring in four plots were Fragaria vesca, Filipendula vulgaris, Pastinaca sativa, and Veronica chamaedrys.

\section{Cornus sanguinea scrubs (CS)}

Cornus sanguinea was the dominant species in the shrub layer of this stage, with a cover of $90-100 \%$ in all five plots. Almost all species in the herb layer had a cover of $<1 \%$. Other species that appeared in four or five plots were growing in the herb layer, and these were Erigeron annuus, Centaurea jacea, Ajuga reptans, Clinopodium vulgare, Fragaria vesca, Veronica chamaedrys, and Rubus plicatus, as well as seedlings of $C$. sanguinea, Prunus spinosa, and Euonymus europaeus.

\section{Late-successional Populus tremula forest stage (PT)}

This stage of late forest succession was characterized by the dominance of Populus tremula in the tree layer. In the shrub layer of this stage, Cornus sanguinea had a somewhat higher dominance than that of other species and occurred in all five plots, whereas Corylus avellana occurred in four plots, also with higher overall abundance than that of other shrub species. In the herb layer, almost all species had a cover $<1 \%$. The most frequent species in the herb layer were seedlings of Carpinus betulus and Cornus sanguinea, appearing in all five plots, and Hedera helix, also appearing in all five plots. These were followed by seedlings of Prunus spinosa and Prunus avium, occurring in four plots.

\section{Late-successional oak-hornbeam forest stage $(\mathrm{OH})$}

This was the last successional stage within the analyzed chronosequence, and it was closest to the terminal (i.e. climax) forest. This stage was dominated by Carpinus betulus in the tree layer. Besides $C$. betulus, Quercus robur appeared in the tree layer of three plots, and Populus tremula in the tree layer of two plots. In the shrub layer, only Corylus avellana appeared in four plots. In the herb layer, the species occurring in all five plots were Epimedium alpinum (with the highest abundance), Rubus hirtus, and seedlings of $C$. betulus. These were followed by Ajuga reptans, Hedera helix, Primula vulgaris, and seedlings of $Q$. robur and Crataegus monogyna, which all occurred in four plots.

\subsection{Differences in soil chemistry between early and late succession}


The results suggested that after grassland abandonment, the SOC and SOM contents in the A horizon increased by $16 \mathrm{~g} \mathrm{~kg}^{-1}$ and $28 \mathrm{~g} \mathrm{~kg}^{-1}$ on average, respectively $(P<0.05)$, in the late-successional forest stages (Table 1 and Table A2). The forest stages also had a higher $\mathrm{C}: \mathrm{N}$ ratio than that of grassland stages $(P<0.0001)$, and a higher $\mathrm{C}: \mathrm{S}$ ratio than that of grassland stages $(P<0.05)$ in the $A$ horizon, whereas soil total $\mathrm{N}$ and $\mathrm{S}$ concentrations and soil $\mathrm{N}: \mathrm{S}$ ratio remained unaltered $(P>0.05)$ (Table 1$)$. The results also suggested that the concentration of $\mathrm{P}_{\mathrm{A}}$ in the $\mathrm{A}$ horizon did not decrease in the forest stages compared to that in grassland stages. The late-successional forest stages also significantly increased the $K_{A}$ concentration in the $A$ horizon $(P<0.05)$ compared to that of grassland stages, whereas the concentrations of total $\mathrm{Mn}, \mathrm{Zn}, \mathrm{Cu}, \mathrm{Ni}$, and Fe remained unaltered in forest $\mathrm{A}$ horizon $(P>0.05)($ Table 1$)$. Detailed results of our soil laboratory analyses are given in Table A2.

\section{Discussion}

\subsection{How plant community composition changed during secondary succession}

Secondary succession in the analyzed chronosequence seemed to progress in the following manner. After the abandonment of haypastures, Brachypodium pinnatum completely colonized the habitat, reaching a cover of $>75 \%$, and as a consequence of this colonization, the cover of most subordinate species remained $<1 \%$. The abundance of grass species from haypastures, such as Helictotrichon pubescens, Anthoxanthum odoratum, and Holcus lanatus, slightly decreased in successional grasslands, whereas Dactylis glomerata and Briza media seemed to persist, and their occurrence increased in successional grasslands. The colonization of haypastures by $B$. pinnatum led to a decrease in the number of haypasture species, but did not induce their complete turnover. Haypastures, which are essentially meadow communities, had the highest species richness and highest total species number among all stages of succession. However, after their colonization by B. pinnatum and the consequential formation of successional grasslands, species richness did not significantly decrease (i.e. it only marginally decreased), and total species number was only slightly lower than that of haypastures. It seemed that some haypasture species from the study area had a stronger ability to cope with the spread of $B$. pinnatum than we expected.

Mid-successional shrub species Cornus sanguinea and Prunus spinosa, which later formed scrub stages in the study area, established their seedlings within the successional grasslands. During the midsuccessional scrub stage of succession, $C$. sanguinea gained a complete dominance over the community, with a cover of $90-100 \%$, and almost all species in the herb layer under its canopy persisted with a cover of $<1 \%$. Only Rubus plicatus occurred within the scrub stage with a somewhat high overall abundance because it was able to intertwine its stems around the branches of $C$. sanguinea, thus being able to acquire more sunlight for its growth. Euonymus europaeus, a mid-successional shrub species which was also frequent in the study area, began to occur with a somewhat high frequency during the scrub stage of succession; however, its cover did not reach high values within $C$. sanguinea scrubs. Carpinus betulus, a tree species specific for the last successional stage in the analyzed chronosequence, already appeared in the herb layer of the scrub stage in the form of seedlings under the dense canopy of $C$. sanguinea. 
Interestingly, the invasive Erigeron annuus was frequent in haypastures, ceased after B. pinnatum spread, and later appeared during the $C$. sanguinea scrub stage.

Late succession began with the development of the forest stage in which Populus tremula was the dominant species in the tree layer. Betula pendula was also found in the tree layer of this stage, and $C$. betulus, a tree species later dominant in the last successional stage, was already present in the tree layer of the $P$. tremula stage. $C$. sanguinea remained present in the shrub layer under the dense $P$. tremula canopy, but its dominance decreased compared to that in the previous scrub stage. In the shrub layer, Corylus avellana, a species that was not apparent in the previous stages of succession, seemed to have formed its bushes during the $P$. tremula stage. In the herb layer of this stage, $C$. betulus seedlings were frequent, and seedlings of $C$. sanguinea and Prunus spinosa still survived in these shaded conditions. Hedera helix, a species that is most often highly abundant in climax forests, was already frequent under the $P$. tremula stage, but with small abundance. In addition, Epimedium alpinum, a species also characteristic for climax forests, was already established in some of the plots during the $P$. tremula stage.

The last successional stage of the analyzed chronosequence was dominated by $C$. betulus in the tree layer, and Quercus robur was found besides it, but with lower frequency and abundance. This last stage was however only an approximate for true climax forests that were once present in the study area, but disappeared as a consequence of anthropogenic management (i.e. extraction of wood for fuel). This was also the reason why plots of $100 \mathrm{~m}^{2}$ were adequate for the purposes of representing the forest stages in the study area, instead of the usual $400 \mathrm{~m}^{2}$ plots which are used for investigating intact original forests. In this stage, $C$. avellana remained frequent in the shrub layer. Rubus hirtus, a species that only occasionally occurred in the previous successional stages, became frequent in the herb layer of the $C$. betulus forest stage. The dominant species in the herb layer under the $C$. betulus canopy was $E$. alpinum, which indicated that these late-successional forest stages are the most similar to those of potential climax forests in the study area.

The ability of species to survive within different successional stages throughout the investigated sequence differed. For example, species that showed an ability to survive through all stages were Ajuga reptans and Fragaria vesca. In addition, Viola hirta was not present in haypastures, but it appeared after the development of successional grasslands and persisted throughout the succession, including the last forest stage. The survival of Veronica chamaedrys was also uninterrupted from haypastures all the way to the $C$. sanguinea scrub stage, and a similar response was found for Clinopodium vulgare. In the herb layer, $C$. sanguinea and $P$. spinosa successfully grew all the way from the successional grassland stage to the late-successional $P$. tremula forest stage.

\subsection{How secondary succession altered the soil chemical properties}


Late-successional forest stages of the secondary succession after grassland abandonment increased the SOC and SOM contents in the A horizon, but the increase was not too great considering that the mean SOC and SOM contents in the early-successional grassland stages were $41 \mathrm{~g} \mathrm{~kg}^{-1}$ and $71 \mathrm{~g} \mathrm{~kg}^{-1}$, respectively, and that the in late-successional forest stages were $57 \mathrm{~g} \mathrm{~kg}^{-1}$ and $99 \mathrm{~g} \mathrm{~kg}^{-1}$, respectively. In addition, total soil $\mathrm{N}$ and $\mathrm{S}$ did not increase after the development of late-successional forest stages, even though this could be expected because of high organic matter content in forest soils which organic $\mathrm{N}$ and S originate from (Johnson, 1992; David et al., 1982). On the other hand, soil C:N and C:S ratios in the A horizon increased in late-successional forest stages compared to those in early-successional grassland stages. The changes in stoichiometric ratios of nutrients in soil, litter, and plant tissues that describe the nutrient limitation during succession are well studied (Jiao et al., 2013; Liu et al., 2020; Ouyang et al., 2017; Liang et al., 2017; Huan et al., 2017). Increased soil C: $\mathrm{N}$ ratio under forest stages usually indicates that $\mathrm{N}$ mineralization in these stages is somewhat slower than that in grasslands. Studies have suggested that $\mathrm{N}$ mineralization is slower in forest soils than in the soils of early successional stages, and that this is due to various processes related to inhibition of nitrification (Rice and Pancholy, 1972; Rice and Pancholy, 1973; Todd et al., 1975). However, the results of studies that compared N mineralization in forest stages and that in early successional stages are often mixed (Robertson and Vitousek, 1981; Vitousek et al., 1989; Yan et al., 2009), thus, a soil C:N ratio solely is not necessarily a safe measure for evaluating $\mathrm{N}$ mineralization rates.

In the present study, after grassland abandonment, late-successional forest stages greatly increased the $\mathrm{K}_{\mathrm{A}}$ concentration in the A horizon. As the effects of secondary succession on the soil $\mathrm{K}$ pool are still understudied, it is hard to make a generalized conclusion about $\mathrm{K}$ cycling during succession. The increase in soil $\mathrm{K}$ pool following secondary succession has been reported in several studies (Feng et al., 2007; Wang et al., 2010; Wen et al., 2005; Liu and Huang 2005; Meng et al., 2010); however, available K and total $\mathrm{K}$ pools do not necessarily follow the same trend during succession. It is hard to conclude which exact reasons underlie the increased $\mathrm{K}_{\mathrm{A}}$ concentration under forest stages in the present study. Either trees possess an ability to substitute $\mathrm{K}^{+}$from the crystal lattice of clay minerals with $\mathrm{H}^{+}$, thus efficiently extracting it into the soil labile pool, or they are able to efficiently increase its concentration through leaf litter deposition. As the soil was sampled from the depth of $\leq 10 \mathrm{~cm}$, our opinion is that both processes are likely to simultaneously contribute to the $\mathrm{K}$ supply at this soil depth. However, further studies on the plant nutritional status and litter decomposition rates during succession are required to clarify this.

On the other hand, late-successional forest stages neither increased nor decreased the $\mathrm{P}_{\mathrm{A}}$, total $\mathrm{Mn}, \mathrm{Zn}$, $\mathrm{Cu}, \mathrm{Ni}$, and Fe concentration in the A horizon. This suggested that despite the fact that in forest ecosystems, most nutrients are locked within the tree biomass, late-successional forest stages in the present study were still able to efficiently retain $\mathrm{P}_{\mathrm{A}}$ and micronutrients within their $\mathrm{A}$ horizons and inhibit the decline in their pools, thus saving them for their development during vegetation period. This is especially important for $\mathrm{P}_{\mathrm{A}}$, which had a low concentration in the soils of both grassland and forest

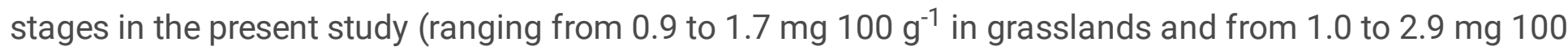
$\mathrm{g}^{-1}$ in forests), and because $\mathrm{P}$ is often the most limiting macronutrient in natural soils which practically 
cannot be supplied from atmosphere (Vitousek et al., 1988). As trees require $\mathrm{P}$ for their growth and lock it inside their biomass, they remove large amounts of $P$ from the nutrient cycle; thus, the further $P$ supply of the forest soil depends either on $\mathrm{P}$ turnover by litter or further weathering of the parent material. Trees probably possess the ability to obtain $\mathrm{P}$ through exudation of organic acids originating from roots or from humus substances, which could enhance the dissolution of hardly soluble P (see Fox, 1995); however, it is also possible that in the present study, trees retained the $\mathrm{P}_{\mathrm{A}}$ in the A horizon through litter deposition.

The advantage of the present study was that it showed that on the same soil type influenced by the same pedogenic factors, late succession increased the SOC and SOM content, along with the plant available $\mathrm{K}$ pool, but it also retained the pools of $\mathrm{P}$ and micronutrients. The limitation of this study is that it only focused on the general differences in soil chemistry between early and late succession, but it did not account for these differences between every single stage of succession. Thus, further studies on this topic should focus on analyzing the differences in soil chemistry between all stages of succession, and try to link the observed changes with the dominant plant species within these stages.

From the perspective of vegetation ecology, this study showed the differences in community composition following secondary succession using phytosociological field methods, and it also showed which species survive in different stages of succession. These kind of studies are still rare in Europe as very hard effort is required to study such dense and hardly accessible mid-successional scrub stages of the phytosociological class Crataego-Prunetea Tx. 1962 nom. conserv. propos (see Škvorc et al., 2017), which are only accessible by knee or army crawling. However, in order to better understand the community changes during the succession of the investigated oak-hornbeam forests in the future, a larger sample size is required, and all stages of succession should be studied using the scale of Barkman (1964), so that other measures of diversity could be assessed.

\section{Conclusions}

- Total species number generally decreased following secondary succession; as the initial stage of succession, haypastures had the highest total number of species, whereas late-successional Populus tremula forest stage had the lowest total number of species.

- Species exhibiting the ability to survive through almost all five successional stages were Ajuga reptans, Fragaria vesca, Cornus sanguinea, Prunus spinosa, and Viola hirta.

- Veronica chamaedrys, Clinopodium vulgare, Agrimonia eupatoria, and (with lower frequency) Centaurea jacea were present from the initial succession stage to the scrub stage, but mostly ceased after the development of late-successional forest stages. The occurrence of other species was mostly stage-specific.

- After grassland abandonment, the A horizon of late-successional forest stages had higher SOC and SOM content, plant available $\mathrm{K}$ concentration, and $\mathrm{C}: \mathrm{N}$ and $\mathrm{C}: \mathrm{S}$ ratios than those of the $\mathrm{A}$ horizon of early-successional grassland stages. 
- The concentrations of plant available P and micronutrients did not decrease after the development of late-successional forest stages, indicating that their pools were efficiently retained in the forest soil despite the fact that their large amounts were already locked within the tree biomass and excluded from the nutrient cycle. Furthermore, despite the increased SOM content, total concentrations of $\mathrm{N}$ and $\mathrm{S}$ did not increase after the development of late-successional forest stages.

\section{Declarations}

\section{Code availability}

No custom made code was used in the preparation of this manuscript

\section{Data availability}

The data from this manuscript were not deposited in any online data repositories

\section{Author contribution}

Study conceptualization and manuscript preparation: A. J.; phytosociological survey: A. J. and D. P.; soil laboratory analyses: A. P. and Ž. Z.; editorial advice: D. P. and Ž. Z.

\section{Acknowledgments}

Thanks to dr. Irena Šapić and dr. Dario Baričević for various discussions about the potentials of researching the understudied vegetation succession in Croatia.

\section{References}

Barkman, J.J., Doing, H., Segal, S.: Kritische Bemerkungen und Vorschläge zur Quantitativen Vegetationsanalyse, Acta. Bot. Neerl., 13, 394-419, 1964

Bautista-Cruz, A. and Del Castillo, R.F.: Soil changes during secondary succession in a tropical montane cloud forest area, Soil Sci. Soc. Am. J., 69.3, 906-914, 2005.

Bogunović, M., Vidaček, Ž., Racz, Z., Husnjak, S., Sraka, M.: Soil maps of Croatia-FAO UNESCO. Zagreb, Croatia, Department of Soil Science, Faculty of Agriculture, University of Zagreb, 1998.

Braun-Blanquet, J.: Pflanzensoziologie. Grundzüge der Vegetationskunde. 3. Aufl.- Springer, Wien-New York, 865 pp, 1964

Bukovac, J., Poljak, M., Šušnjar, M., Čakalo, M.: Basic geological map 1:100 000. Interpreter for the sheet Črnomelj, L 33-91, Department of Geology, Zagreb and Department of Geology, Ljubljana, Belgrade, 1984. 
Čarni, A., Košir, P., Marinšek, A., Šilc, U., Zelnik, I.: Changes in structure, floristic composition and chemical soil properties in a succession of birch forests, Period. Biol., 109.1, 13-20, 2007.

Čarni, A., Zimmermann, Z., Juvan, N., Paušič, A., Szabó, G., Bartha, S.: An example of fast old field succession in a traditionally managed rural landscape on the Slovenian Karst, Hacquetia, 20.1, 177-188, 2021.

Cortez, J., Garnier, E., Pérez-Harguindeguy, N., Debussche, M., Gillon, D.: Plant traits, litter quality and decomposition in a Mediterranean old-field succession, Plant. Soil., 296.1, 19-34, 2007.

Dakskobler, I.: Development of vegetation on gravel sites of the Idrijca River in western Slovenia, Fol. Biol. et Geol., 51.2, 5-90, 2010. (in Slovenian)

David, M.B., Mitchell, M.J., Nakas, J.P.: Organic and inorganic sulfur constituents of a forest soil and their relationship to microbial activity, Soil Sci. Soc. Am. J., 46.4, 847-852, 1982.

Egner, H., Riehm, H., Domingo, W.R.: Untersuchungen über die chemische Bodenanalyse als Grundlage für die Beurteilung des Nährstoffzustandes der Böden. II Chemische Extraktionsmethoden zur Phosphor und Kalium. Kungl. Lantbruk, Annaler 26, 45-61, 1960.

Feldpausch, T.R., Rondon, M.A., Fernandes, E.C., Riha, S.J., Wandelli, E.: Carbon and nutrient accumulation in secondary forests regenerating on pastures in central Amazonia, Ecol. Appl., 14(sp4), 164-176, 2004.

Feng, D., Hong-Bo, S., Lun, S., Zong-Suo, L., Ming-An, S.: Secondary succession and its effects on soil moisture and nutrition in abandoned old-fields of hilly region of Loess Plateau, China, Colloids. Surf. B., $58.2,278-285,2007$.

Fox, T.R.: The influence of low-molecular-weight organic acids on properties and processes in forest soils, Carbon forms and functions in forest soils, 43-62, 1995.

Hammer, Ø., Harper, D.A., Ryan, P.D.: PAST: Paleontological statistics software package for education and data analysis, Palaeontol. Electron., 4.1: 9, 2001.

HRN EN ISO 13196:2015: Soil quality - Screening soils for selected elements by energy-dispersive X-ray fluorescence spectrometry using a handheld or portable instrument (ISO 13196:2013; EN ISO 13196:2015)

HRN ISO 10694:2004: Soil quality - Determination of organic and total carbon content after dry combustion (elementary analysis) (ISO 10694:1995)

HRN ISO 13878:2004: Soil quality - Determination of total nitrogen content by dry combustion (elemental analysis) (ISO 13878:1998) 
HRN ISO 15178:2005: Soil quality - Determination of total sulfur content by dry combustion (ISO 15178:2000)

Huang, Y., Ma, Y., Zhao, K., Niklaus, P.A., Schmid, B., He, J.S.: Positive effects of tree species diversity on litterfall quantity and quality along a secondary successional chronosequence in a subtropical forest, $\mathrm{J}$ Plant Ecol, 10.1: 28-35, doi: 10.1093/jpe/rtw115, 2017.

Husnjak, S.: Soil systematics of Croatia, Croatian University Press, Zagreb, 2014. (in Croatian).

ISO 10390:2005 Soil quality - Determination of pH, ISO/TC 190/SC 3 Chemical and physical characterization

ISO 11464:2006 Soil quality - Pre-treatment of samples for physico-chemical analysis, ISO/TC 190/SC 3 IUSS Working Group WRB: World Reference Base for Soil Resources 2014, update 2015 International soil classification system for naming soils and creating legends for soil maps, World Soil Resources Reports No. 106. FAO, Rome, 2015.

Jiao, F., Wen, Z.M., An, S.S., Yuan, Z.: Successional changes in soil stoichiometry after land abandonment in Loess Plateau, China, Ecol. Eng,m 58, 249-254, doi: 10.1016/j.ecoleng.2013.06.036., 2013.

Johnson DW (1992). Nitrogen retention in forest soils. J Environ Qual 21.1: 1-12.

Krstonošić, D., Guzmić, M., Franjić, J., Škvorc, Ž., Sever, K.: Flora of thermophilous grasslands in succession on the southern slopes of Mt. Papuk, Journal of the Croatian Botanical Society, 4.1, 4-21, 2016. (In Croatian).

Kutnjak, H.: Impact of agroecological factors on vegetation succession of grasslands in fir-beech forest zone on Medvednica mountain, Dissertation, Department of Biology, Faculty of Science, Zagreb, Croatia, 2010. (in Croatian).

Lambert, R., Reiners, W., Lang, G.: Loss of Mass and Chemical Change in Decaying Boles of a Subalpine Balsam Fir Forest. Ecology., 61.6, 1460-1473, doi: 10.2307/1939054, 1980.

Liu, H., Huang, J.: Dynamics of soil properties under secondary succession forest communities in Mt. Jinyun], Ying Yong Sheng Tai Xue Bao = J. Appl. Ecol., 16.11, 2041-2046, PMID: 16471336, 2005.

Liu, W., Fu, S., Yan, S., Ren, C., Wu, S., Deng, J., Li, B., Han, X., Yang, G.: Responses of plant community to the linkages in plant-soil C:N:P stoichiometry during secondary succession of abandoned farmlands, China, J., 12.2, 215-226, doi: 10.1007/s40333-020-0009-6, 2020.

Meng, J-H., Lu, Y., Liu, G., Wang, Y-X.: Comparison study on soil chemical characteristics in tropical natural forests in different succession stages, Chinese Academy of Forestry, 23.5, 791-795, ISSN: 10011498, 2010. 
Odum, E.P.: The Strategy of Ecosystem Development: An understanding of ecological succession provides a basis for resolving man's conflict with nature, Science, 164.3877, 262-270, 1969.

Olrik, D.C., Kjaer, E.D.: The reproductive success of a Quercus petraeax Q. robur F1-hybrid in back-crossing situations, Ann. For. Sci., 64.1, 37-45, doi: 10.1051/forest:2006086, 2007.

Poorter, L., Van de Plassche, M., Willems, S., Boot, R.G.A.: Leaf traits and herbivory rates of tropical tree species differing in successional status, Plant. Biol., 6.06, 746-754, 2004.

Rice, E.L., Pancholy, S.K.: Inhibition of nitrification by climax vegetation, Am. J. Bot,. 59, 1033-1040, 1972.

Rice, E.L., Pancholy, S.K.: Inhibition of nitrification by climax ecosystems. II. Additional evidence and possible role of tannins, Am. J. Bot,. 60, 691-702, 1973.

Robertson, G.P., Vitousek, P.M.: Nitrification potentials in primary and secondary succession, Ecology, 62.2, 376-386, 1981.

Shuai, O., Xiang, W., Gou, M., Lei, P., Chen, L., Deng, X., Zhao, Z.: Variations in soil carbon, nitrogen, phosphorus and stoichiometry along forest succession in southern China, Biogeosci. Discuss., 1-27, doi: $10.5194 / \mathrm{bg}-2017-408,2017 .$.

Škorić, A.: Manual for Soil Science Research. Faculty of Agriculture, Zagreb, 1982. (in Croatian).

Škvorc, Ž., Jasprica, N., Alegro, A., Kovačić, S., Franjić, J., Krstonošić, D., Vraneša, A., Čarni, A.: Vegetation of Croatia: Phytosociological classification of the high-rank syntax, Acta. Bot. Croat., 76.2, 200-224., 2017.

The Plant List: Version 1.1. [accessed Nov 21 2021], 2013., http://www.theplantlist.org/.

Todd, R.L., Swank, W.T., Douglass, J.E., Kerr, P.C., Brockway, D.L., Monk, C.D.: The relationship between nitrate concentration in southern Appalachian mountain streams and the terrestrial nitrifiers, AgroEcosystems, 2.2, 137-142, 1975.

Van der Maarel, E.: Transformation of cover-abundance values for appropriate numerical treatment Alternatives to the proposals by Podani, J. Veg. Sci,. 18.5, 767-770, 2007.

Vitousek, P.M., Fahey, T., Johnson, D.W., Swift, M.J.: Element interactions in forest ecosystems: succession, allometry and input-output budgets, Biogeochemistry, 5.1, 7-34, doi: 10.1007/BF02180316, 1988.

Vitousek, P.M., Matson, P.A., Van Cleve, K.: Nitrogen availability and nitrification during succession: primary, secondary, and old-field seres, Plant. soil., 115.2, 229-239, 1989. 
Vitousek, P.M. and Reiners, W.A.: Ecosystem succession and nutrient retention: a hypothesis, BioScience, $25.6,376-381,1975$.

Wang, B., Liu, G.B., Xue, S., Zhu, B.: Changes in soil physico-chemical and microbiological properties during natural succession on abandoned farmland in the Loess Plateau, Environ. Earth. Sci., 62.5, 915925, doi:10.1007/s12665-010-0577-4, 2010.

Wen, Z., Jiao, F., Liu, B., Bu, Y., Jiao, J.: Natural vegetation restoration and soil nutrient dynamics of abandoned farmlands in forest-steppe zone on Loess Plateau, Ying Yong Sheng Tai Xue Bao = J. Appl. Ecol., 16.11, 2025-2029, PMID: 16471333, 2005.

Xingyu, L., Shirong, L., Hui, W., Jingxin, W.: Variation of carbon and nitrogen stoichiometry along a chronosequence of natural temperate forest in northeastern China, J. Plant. Ecol., 11.3, 339-350., doi: 10.1093/jpe/rtx008, 2018.

Yan, E.R., Wang, X.H., Guo, M., Zhong, Q., Zhou, W, Li, J.F.: Temporal patterns of net soil N mineralization and nitrification through secondary succession in the subtropical forests of eastern China, Plant. Soil., 320.1, 181-194, doi: 10.1007/s11104-008-9883-y, 2009.

Zaninović, K., Gajić-Čapka, M., Perčec Tadić, M., Vučetić, M., Milković, J., Bajić, A., Cindrić, K., Cvitan, L., Katušin, Z., Kaučić, D., Likso, T., Lončar, E., Lončar, Ž., Mihajlović, D., Pandžić, K., Patarčić, M., Srnec, L., Vučetić, V.: Climate atlas of Croatia, Zagreb, Croatia, State Department of Hydrometeorology, 2008.

\section{Tables}

Table 1:

The results of blocked ANOVA for the differences in soil chemical properties between early succession (i.e. grassland stages) and late succession (i.e. forest stages) $(n=6)$

\begin{tabular}{|c|c|c|c|}
\hline Soil variable & $\mathrm{F}$ & Block effect & Succession effect \\
\hline $\mathrm{pH} 1 \mathrm{M} \mathrm{KCl}$ & 0.0003 & 0.19 & 0.99 \\
\hline SOC, $\mathrm{g} \mathrm{kg}^{-1}$ & 8.28 & 0.81 & 0.02 \\
\hline SOM, $\mathrm{g} \mathrm{kg}^{-1}$ & 8.28 & 0.80 & 0.02 \\
\hline $\mathrm{N}, \mathrm{g} \mathrm{kg}^{-1}$ & 0.29 & 0.84 & 0.61 \\
\hline $\mathrm{S}, \mathrm{g} \mathrm{kg}^{-1}$ & 1.17 & 0.55 & 0.30 \\
\hline $\mathrm{C}: \mathrm{N}$ & 296 & 0.03 & $<0.0001$ \\
\hline $\mathrm{C}: \mathrm{S}$ & 7.32 & 0.50 & 0.02 \\
\hline $\mathrm{N}: \mathrm{S}$ & 0.20 & 0.80 & 0.67 \\
\hline $\mathrm{P}_{\mathrm{A}}, \mathrm{mg} 100 \mathrm{~g}^{-1}$ & 2.28 & 0.57 & 0.19 \\
\hline $\mathrm{K}_{\mathrm{A}}, \mathrm{mg} 100 \mathrm{~g}^{-1}$ & 7.41 & 0.01 & 0.04 \\
\hline $\mathrm{Mn}, \mathrm{mg} \mathrm{kg}^{-1}$ & 0.11 & 0.35 & 0.75 \\
\hline $\mathrm{Zn}, \mathrm{mg} \mathrm{kg}^{-1}$ & 0.55 & 0.49 & 0.48 \\
\hline $\mathrm{Cu}, \mathrm{mg} \mathrm{kg}^{-1}$ & 0.21 & 0.75 & 0.66 \\
\hline $\mathrm{Ni}, \mathrm{mg} \mathrm{kg}^{-1}$ & 0.99 & 0.16 & 0.36 \\
\hline $\mathrm{Fe}, \mathrm{g} \mathrm{kg}^{-1}$ & 1.49 & 0.49 & 0.25 \\
\hline
\end{tabular}


If the block effect was insignificant $(\mathrm{P}>0.25)$, then the $\mathrm{F}$ and $\mathrm{P}$ values for the succession effect corresponded to those of simple one-way ANOVA, whereas if the block effect was significant $(P<0.25)$, then the $F$ and $P$ values for the succession effect corresponded to that of blocked ANOVA (i.e. two-way ANOVA without replication); SOC - soil organic carbon, SOM - soil organic matter, N - soil total nitrogen, S - soil total sulfur, C:N - soil carbon to nitrogen ratio, C:S - soil carbon to sulfur ratio, $\mathrm{N}: \mathrm{S}$ - soil nitrogen to sulfur ratio, $\mathrm{P}_{\mathrm{A}}$ and $\mathrm{K}_{\mathrm{A}}$ - ammonium lactateextracted plant available phosphorus and plant available potassium, respectively, Mn - soil total manganese, Zn - soil total zinc, $\mathrm{Cu}$ - soil total copper, $\mathrm{Ni}$ - soil total nickel, $\mathrm{Fe}$ - soil total iron

\section{Figures}

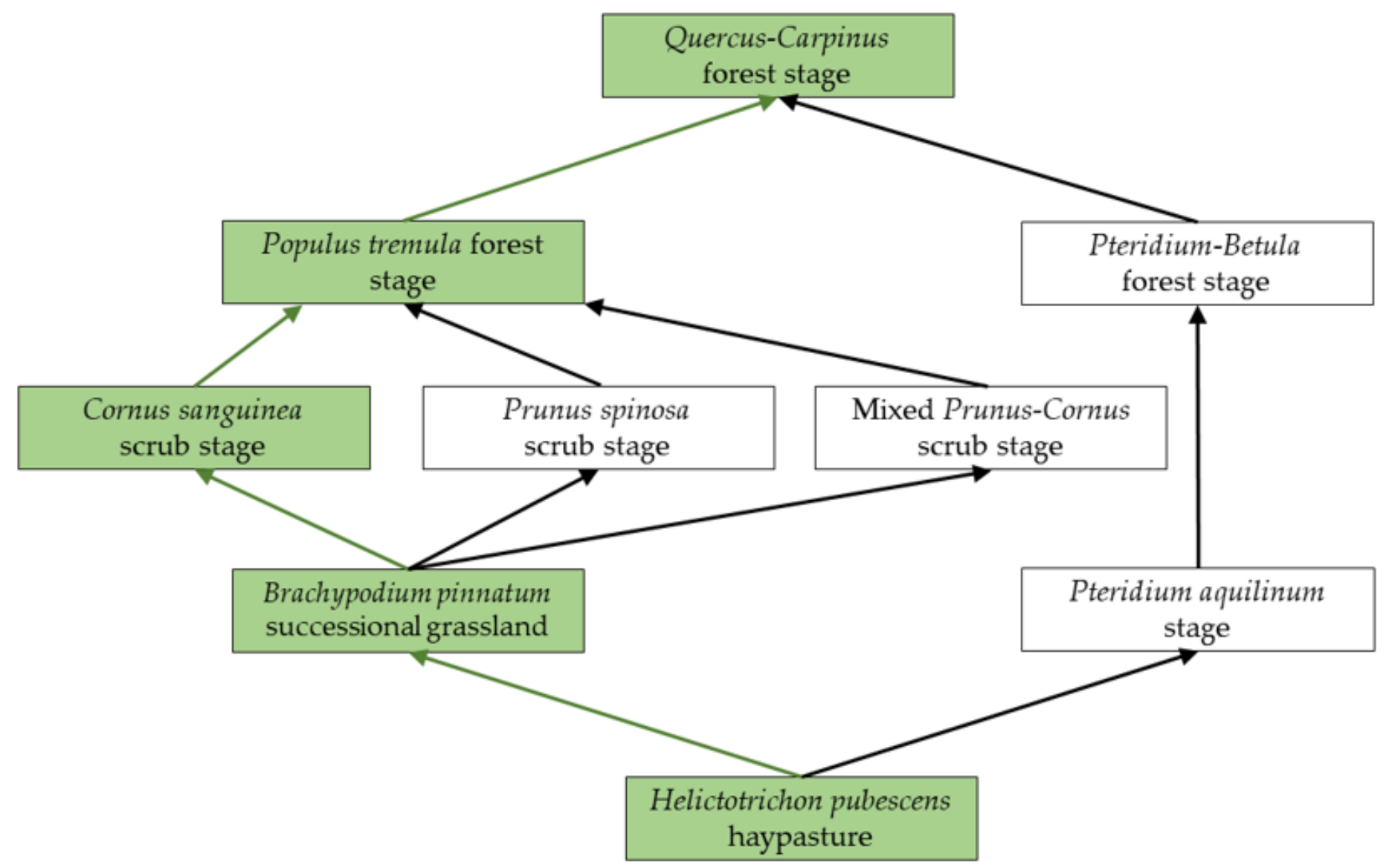

\section{Figure 1}

Different successional pathways of forest development apparent within the study area (the sequence marked in green was analyzed in the present study). Legend: Helictotrichon pubescens haypasture grasslands used as meadows, which also experience occasional rotational grazing by sheep; Brachypodium pinnatum successional grassland - successional grasslands dominated by Brachypodium pinnatum with patches of Calamagrostis epigejos; Pteridium aquilinum stage - stands of P. aquilinum; Cornus sanguinea scrub stage - mid-succession dominated by C. sanguinea; Prunus spinosa scrub stage - mid-succession dominated by P. spinosa; mixed Prunus-Cornus scrub stage - mid- 
succession with both P. spinosa and C. sanguinea as dominant shrubs; Populus tremula forest stage late-successional forest stage with P. tremula as the dominant tree species, with Betula pendula and Corylus avellana as accompanying species; Pteridium-Betula forest stage - late-successional forest stage with the fern P. aquilinum as the dominant species in the herb layer and B. pendula as the dominant species in the tree layer; Quercus-Carpinus forest stage - late-successional forest stage dominated by Carpinus betulus in the tree layer accompanied by Quercus robur and occasionally Quercus petraea.

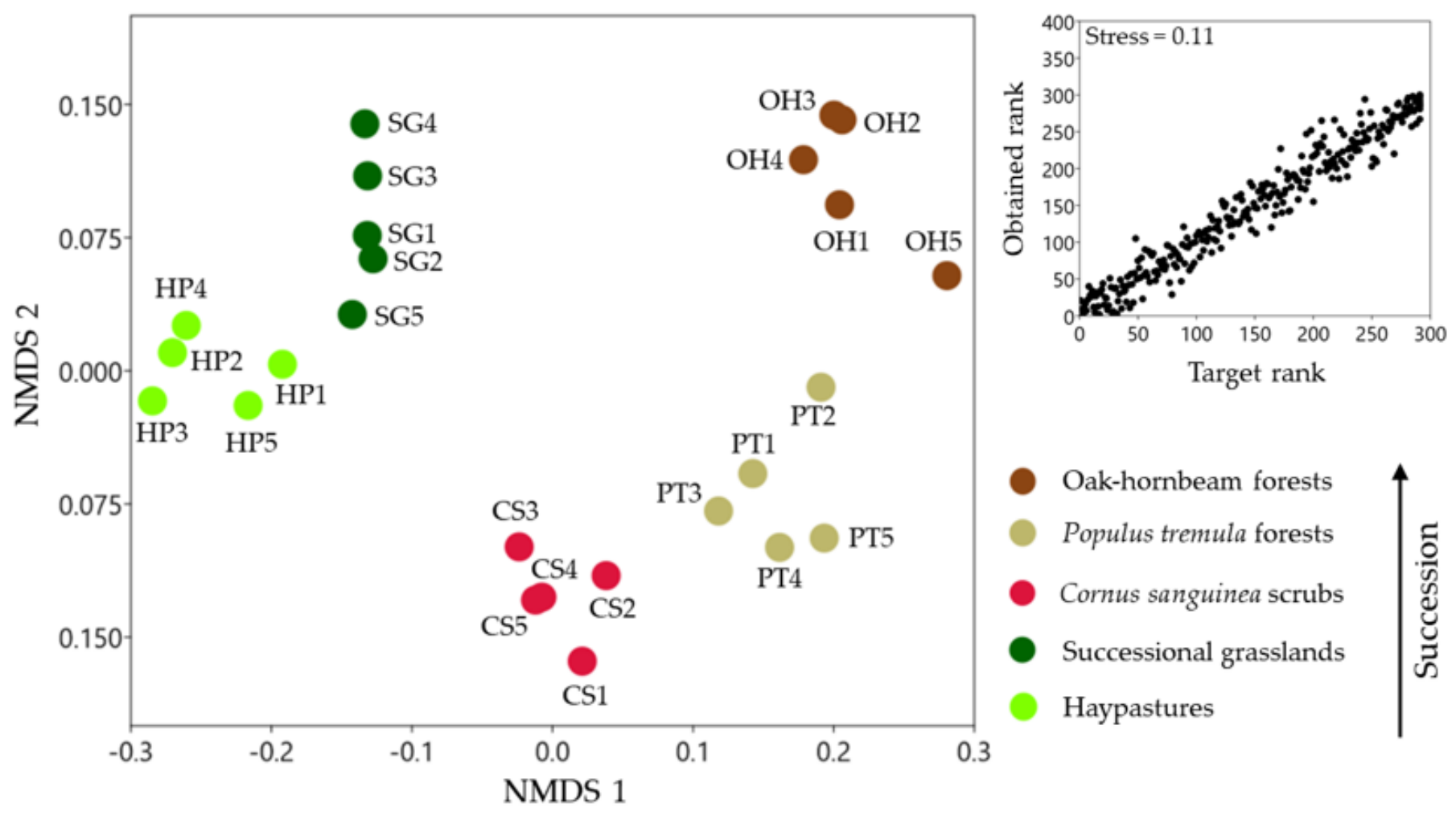

Figure 2

Non-metric multidimensional scaling ordination of successional stages based on community composition differences, obtained by Bray-Curtis dissimilarities. The plot in the upper right corner represents the Shepard plot 

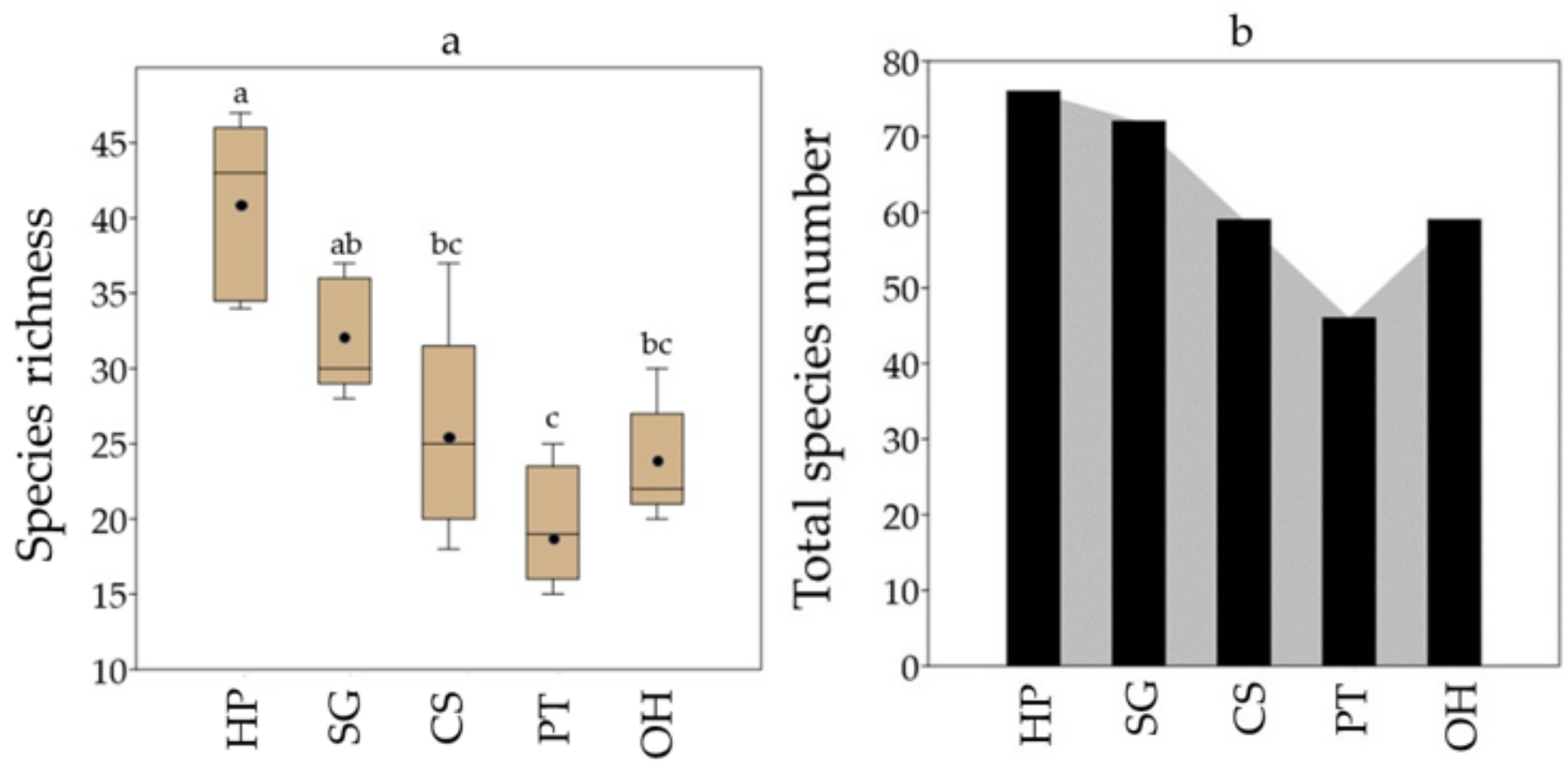

Figure 3

a) Differences in species richness (i.e. species number per unit area, in this case $100 \mathrm{~m} 2$ ) between the different successional stages within the single chronosequence $(n=5)$. Black dots indicate the mean values, and different lowercase letters indicate significant differences at $\mathrm{P}<0.01$ according to Tukey's pairwise comparison test; b) total species number recorded in different successional stages; HP haypasture plots, SG - successional grassland plots, CS - Cornus sanguinea scrub plots, PT - Populus tremula forest plots, $\mathrm{OH}$ - oak-hornbeam forest plots

\section{Supplementary Files}

This is a list of supplementary files associated with this preprint. Click to download.

- AppendixJelinietal.2021.docx 